\title{
The idea of weak sustainability is illegitimate
}

\author{
Katharina Biely ${ }^{1} \cdot$ Dries Maes $^{1} \cdot$ Steven Van Passel $^{1,2}$
}

Received: 24 August 2016/Accepted: 20 October 2016/Published online: 31 October 2016

(C) The Author(s) 2016. This article is published with open access at Springerlink.com

\begin{abstract}
Since the introduction of the sustainability challenge, scientists disagree over the interpretation of the term "sustainability." Weak and strong sustainability are the two main interpretations of sustainability, which are opposing each other. Some researchers stated that the interpretation of the term depends on the context; others disagree pointing out that it always implies the meaning of continuation. The term "sustainability" can be used as attribute, which adds a certain characteristic to the noun. If something can be attributed as being sustainable, it can also be unsustainable. The sustainability challenge consists of shifting from the current unsustainable towards a sustainable system. This paper outlines that the weak sustainability term is illegitimate, as it leads to a contradiction with the acknowledged assumption that the current state is unsustainable. This contradiction is revealed through an analysis of the occurrence of decoupling in agriculture: Agricultural land use could be decoupled from agricultural production, but only with the trade-off of massive increases in fertilizer, pesticide, energy and water usage. This paper outlines an inherent inconsistency within the ongoing discussion about the interpretation of sustainability. Through identifying the invalidity of the weak sustainability interpretation the focus can be shifted form the discourse to the sustainability challenge itself.
\end{abstract}

Keywords Weak sustainability $\cdot$ Strong sustainability $\cdot$ Decoupling $\cdot$ Agriculture

Katharina Biely

katharina.biely@uhasselt.be

1 Centre for Environmental Sciences, Faculty of Business Economics, Hasselt University, Martelarenlaan 42, 3500 Hasselt, Belgium

2 Department of Engineering Management, Faculty of Applied Economics, University of Antwerp, Prinsstraat 13, 2000 Antwerpen, Belgium 


\section{Introduction}

Since the introduction of the sustainability challenge (Clark and Dickson 2003; Juma 2002; Steffen et al. 2011), an intensive debate has been going on whether humans should pursue weak or strong sustainability (Redclift 2005). The scientific community is divided, whereat, to be precise, it is the economic discipline that introduced and keeps arguing about the two possible interpretations of sustainability (Davies 2013). This division can be vividly seen through the existence of two economic schools of thought: environmental (weak) and ecological (strong) economics (Quental et al. 2011; van den Bergh 2001).

Either a scientist chooses color and consequently conducts research that supports their decision or looks for a middle way (Davies 2013) to keep all doors open. Is it essential to share one definition or a common understanding of sustainability? There are at least two adverse effects of not defining sustainability. First, the sustainability term became blurry, allowing everyone to call everything sustainable, without reflecting on what this really means. As a result, we can find creations like sustainable competition (Song 2009), or the most contested one sustainable growth (Brand 2012; Daly 1996, p. 69; Redclift 2005). This leads not only to problems within science, but has also implications for practice. People do not know what sustainability really means, and decision makers can use the term to their advantage. This leads to the second drawback. By not stating what sustainability really means, usually the current economic system is promoted (Pearce 1992; Van Hoogstraten 2001, p. 52). However, the current economic system is the system we want to get rid of in order to get a sustainable economic system. Thus, a state of deadlock was reached were humanity is not progressing much toward the sustainable economic system. Davies (2013) suggests taking a middle way, trying to overcome this deadlock. He argues that this is necessary for two reasons. First technological solutions are not always available and secondly not all people are willing to change their behavior. However, these two arguments are weak. First, even if technology is available technology does not guarantee an absolute decrease in resource consumption, as can be shown by the rebound effect (Alcott 2005,2008 ) and the up to date inability to create absolute decoupling (Krysiak 2006). Second, it is not a question whether people are willing to change their lifestyle. As Meadows (2010) illustrates, if the system collapses, humans have to change, they simply have no choice. Davies (2013) is right in stating that a strategy is needed to get out of the deadlock. Still, it is argued here that a pragmatic solution accommodating both is not helpful, as it circumvents tackling the real challenges such as sufficiency, absolute reduction of resource usage and waste creation, as well as the real provision and enhancement of happiness.

Indeed, this is not the first paper claiming that strong sustainability is the only legitimate interpretation of sustainability (Ekins et al. 2003). However, prior arguments led to a softening of the strong sustainability approach, as they allowed substitutability of noncritical natural capital. Thus, such arguments, similarly to Davies' approach, also suggest a middle way. Since, humans need to use natural resources to survive, such an approach is of course helpful (Trucost 2013). Though, there are too many uncertainties related to the evaluation of non-critical natural capital, ${ }^{1}$ as to understand this approach as solution to the sustainability challenge. Moreover, the preservation of natural capital involves the clarification of critical normative questions (Redclift 2005). In this article, it is argued that the reason for the illegitimacy of the weak sustainability interpretation, also leads to the conclusion that humans tend to underestimate the complexity of the environmental system.

\footnotetext{
${ }^{1}$ Ekins et al. (2003) do also acknowledge these uncertainties and call for caution.
} 
Thus, humans need to be much more humble in their ability to estimate what is critical for human survival. It needs to be emphasized that this paper is not about the measurement of sustainability goals. Rather, it is aimed to illustrate that weak sustainability and the prioritization that comes along with it, is invalid.

In the following section, a short introduction of the sustainability concept is given, followed by a section on the Green Economy and decoupling. Thereafter, we expand on the first incidence of decoupling and its trade-offs. Finally, we conclude unraveling the illegitimacy of the weak sustainability concept.

\section{Sustainability}

It is not aimed to give a detailed analysis of sustainability understandings and what the differences between the two understandings are, as this can be found elsewhere (see for example: Hediger 1999; Jabareen 2008; Quental et al. 2011). However, a brief introduction is provided in order to follow the subsequent argumentation. There is one mainly accepted definition of sustainability:

Sustainable development is development that meets the needs of the present without compromising the ability of future generations to meet their own needs. It contains within it two key concepts: the concept of 'needs', in particular the essential needs of the world's poor, to which overriding priority should be given; and the idea of limitations imposed by the state of technology and social organization on the environment's ability to meet present and future needs. (WCED 1987)

This definition left enough space to give birth to two different interpretations: weak and strong sustainability. Generally sustainability is understood to consist of at least three different aspects: social, environmental and economic. Weak sustainability is characterized by allowing trade-offs between these three aspects. Representatives of this interpretation argue mostly that economic aspects can be traded off for environmental aspects. This is reasoned by the belief and trust in technology, which will permit future generations' well-being with the usage of less resources. Thus, current exploitation of resources is reinvested in the development of technologies that allow to live with less material and energy inputs (and outputs). The basic assumption behind this mechanism is the possibility to decouple economic growth from resource usage (Pearce 1992). Strong sustainability, in contrast, is not such generous with tradeoffs between the different aspects of sustainability. There are variations of the extent to which humans are allowed to destroy the environment for their well-being (Davies 2013; Ekins et al. 2003). However, the main difference is that the economy is not seen as superior to the environment and that technological innovations will not provide the sole solution for the sustainability challenge (Ekins et al. 2003). Basically, representatives of this interpretation call for a fundamental change of the economic system (Daly 1996, p. 48). This short outline of the two interpretations illustrate that they are founded on two completely different mindsets.

\section{The suggested solution to the sustainability challenge: sustainable economy-green economy}

While the term Green Economy became popular only recently, it is a much older idea developed by Pearce, Markandya and Barbier (1989). In 1992, Pearce outlines the ideas of the Green Economy again, stating that it takes the middle road between the two extremes 
of deep ecology and pure neoliberal thinking. Brand (2012) argues that Green Economy is, similarly like the sustainability concept, an empty shell and the new oxymoron. However, taking UNEP's understanding of Green Economy it is clear that it is in line with weak sustainability. In 2009, UNEP started its Green Economy initiative (UNDESA 2012) and published the Global Green New Deal Policy Brief (GGND) that draws on US President Franklin D. Roosevelt's New Deal, which intended to end the Great Depression through governmental spending (UNEP 2009a). This clearly implicates that promoting further growth is one of the three targets of Green Economy proposed by UNEP from 2009 onward. Moreover, economic growth remains unquestioned within the concept of Green Economy indicated by the continuous hope that is put into decoupling (UNEP 2008, 2009b, 2010, 2011b). Probably economic growth within the Green Economy concept developed new prominence through the multiple crises in 2008. In UNEP's "Year Book 2010", Green Economy is presented as a tool that can "hit two birds with one bullet"; jump starting economic growth and protecting the environment (UNEP 2010, p. 14). Hence, the magic key that allows to disentangle economic growth from resource input and output is decoupling.

Decoupling has two specifications, relative and absolute decoupling. The latter means that the absolute resource input decreases while GDP rises; hence, resource use is decreasing in absolute terms. The former describes the incident that resource use per unit GDP declines, while the absolute amount of resource use further increases, but at a slower pace than GDP (Alcott 2008; Behrens et al. 2007; FoEI 2009; Haberl et al. 2004).

However, this promising scenario is in contrast to scientific evidence regarding absolute decoupling. A Friends of the Earth report (FoEI 2009) points out that the world economy today is $30 \%$ less resource intensive than 30 years ago. Still, current data does not indicate that absolute decoupling is possible (Behrens et al. 2007; FoEI 2009; Huesemann and Huesemann 2008; Krausmann et al. 2009). Krausmann et al. (2009) state that absolute decoupling could not be observed throughout the history. The only occasions when resource use in absolute terms declined or stagnated were during times of economic downturn or stagnation. Anyway, some evidence for relative decoupling exists (Steinberger and Roberts 2010).

\section{The first incidence of relative decoupling}

Promoting Green Economy, Pearce (1992, p. 12) states: "Maybe the problem of scale dominates and as fast as we lower the coefficient between growth and environment the scale effect will put us back on some path to doom. We do not know because we have not tried. The problem is that we have not tried the alternatives either. Relying on some spontaneous spiritual green uprising could be risky—it may not happen. Relying on forcible change in attitudes presupposes two imponderables: that people will take it, and that the costs in terms of the suppression of human freedoms are outweighed by the benefits of extended survival." There is some truth in this citation; the discussion around decoupling illustrates the importance of scale once again (Csereklyei and Stern 2015). Still, it is hoped that decoupling will seal the deal. However, it is not true that we do not know if decoupling will work and what effects it will have. Human society has much experience in the working and effect of decoupling as the following example will show.

In classical economy, we can still find resources as important factor within economics, being the limiting factor for economic growth (Daly 1996, p. 3; Gómez-Baggethun et al. 
2010). Land was understood as a limiting factor. Malthus had the opinion that progress will be restricted by land availability. However, this changed fundamentally with the Green Revolution. Through modern technologies and production practices, more could be produced with less (Steffen et al. 2011). This is the fundamental condition for economic and population growth. People could be freed from agricultural work and became available for industrial production (Huesemann and Huesemann 2008; Meadows 2010; Pinstrup-Andersen and Hazell 1985; Rostow 1969). This first incidence of relative decoupling is the very basis of the economic system, that we have now, that permitted the take-off toward the mass consumption society of today.

Figure 1 shows relative decoupling of agricultural output from agricultural land. While global GDP and global agricultural production are increasing, agricultural land remained stable. Huesemann and Huesemann (2008) even provides the example of the US corn production which could decouple in absolute terms for a certain period.

Although it was believed that the new technologies and practices will hardly have any negative effect on the environment (Pinstrup-Andersen and Hazell 1985), it turned out to be the opposite. The increase in agricultural production is owed to the increased usage of fertilizers and energy, as Fig. 2 shows. Increases in fertilizer application outstrip by far increases in arable land (Foley et al. 2011). Although intensification allowed humans to meet growing food demands, the means by which this was and is accomplished are unsustainable (Smith 2013; Tilman et al. 2001). Industrial agriculture is one of the main sources of anthropocentric greenhouse gases (Olivier et al. 2005; Smith et al. 2014). Apart from greenhouse gases, industrial agriculture causes eutrophication, land degradation, sinking water tables, water pollution and loss of biodiversity (Altieri 1998; Meadows 2010; Vitousek et al. 1997). Meadows (2010) using a systems thinking approach illustrate the flaws of the industrial agricultural production system and foreshadowed the land scarcity

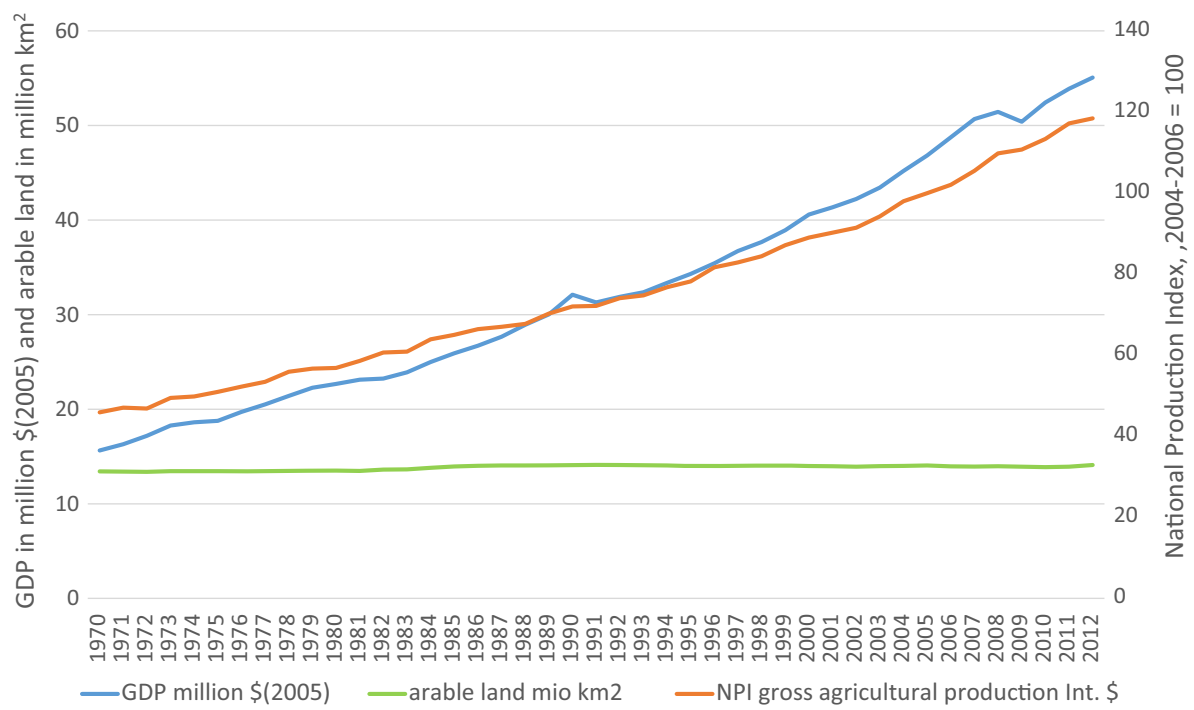

Fig. 1 Decoupling agricultural output from agricultural land. Source: FAO (2016) and own calculation [This is an adaptation of an original work by FAO. Views and opinions expressed in the adaptation are the sole responsibility of the author or authors of the adaptation and are not endorsed by FAO] 
that we are increasingly facing (FAO 2011). Problems caused by industrial agriculture are part of the root cause of the sustainability challenge we are facing (Rockstrom et al. 2009).

The agriculture example illustrates that decoupling has to be dealt with caution, not only because of the aforementioned rebound effect, but also because of the potential to shift a problem from one area to another (Huesemann and Huesemann 2008; Scott 2011). For example, the electric car may be promising to decouple transportation from $\mathrm{CO}_{2}$ emissions (Van Mierlo and Maggetto 2007). Taking the source of electricity into account the environmental impact of electric cars can be greater than that of fossil fuel-powered ones depending on the energy mix (Wilson 2013). Another example are biofuels. Apart from the food versus fuel problem and negative environmental impacts of growing the crops, more energy input is needed for its production than they deliver (Pimentel and Patzek 2005). Another example is plastic. While there are great advantages regarding energy savings of plastic (Andrady and Neal 2009), it also causes massive environmental problems (Cole et al. 2011; Wright et al. 2013). UNEP's Green Economy Report illustrates the belief in decoupling by presenting a promising scenario that accommodates economic growth and the reduction in resource consumption in absolute terms (UNEP 2011a). However, this goal can only be reached through the employment of nuclear energy. Although nuclear energy can reduce $\mathrm{CO}_{2}$ emissions (Duffey 2005; Kessler 2002), it has its trade-offs related to nuclear waste, mining or safety. Nuclear energy allows to shift the problem to another area, in the presumably far future. As the nuclear disaster in Fukushima showed, problems created by technology may be more imminent than thought (Blowers 2011). Moreover, Dittmar (2012) points out that peak uranium will not allow the green economy scenario to come true. The trust in technology, born in times of industrial revolution, (Kastenberg et al. 2005) peaks in self-deception (Nel and Ward 2015) in order to keep the current system alive. The insight that technology may cause more harm than cure
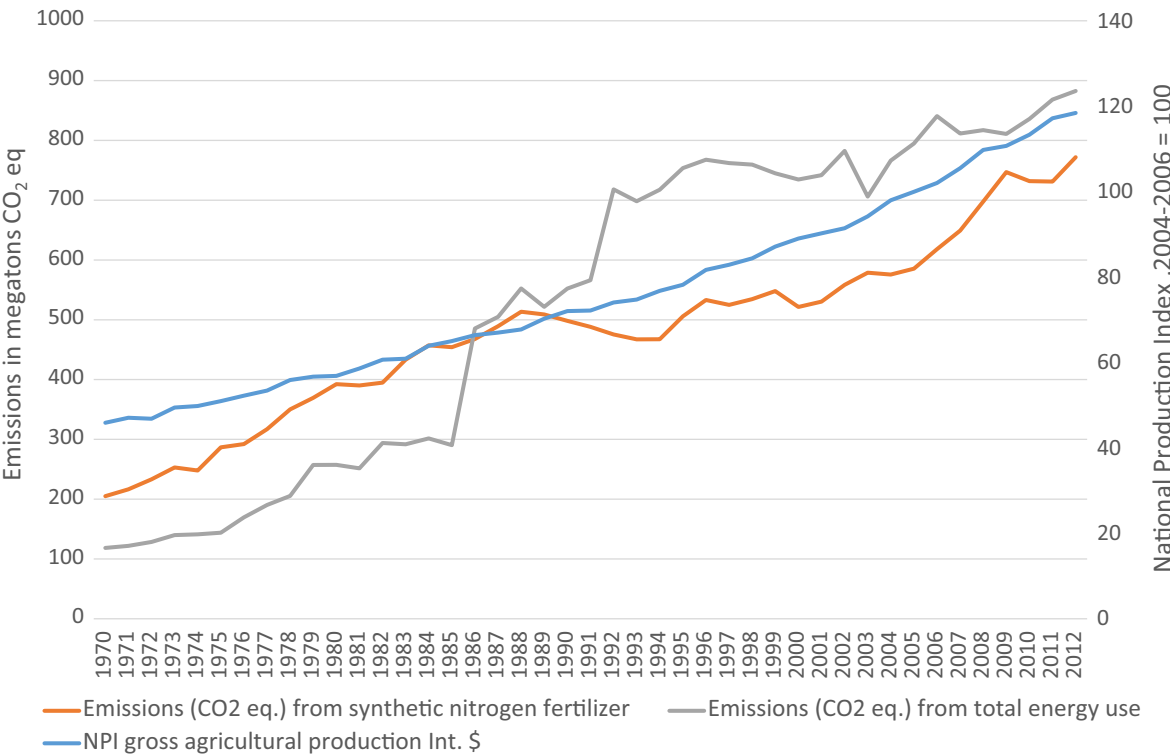

Fig. 2 Joint rise of agricultural emissions with agricultural output. Source: FAO and own calculation [This is an adaptation of an original work by FAO. Views and opinions expressed in the adaptation are the sole responsibility of the author or authors of the adaptation and are not endorsed by FAO] 
is, however, not recent as the article by Burton (1968) exemplifies. In 1968, he wrote: "The Achilles heel of the technologists' approach is, of course, that the present problems of environmental quality arise precisely from the application of technological solutions to problems in the past. The new technologies now being developed may in their turn prove to be only palliatives that will pile up greater difficulties to be confronted at a later date" (ibid., p. 478).

\section{The illegitimacy of weak sustainably}

In fact, the term sustainability stems from forestry, describing a management practice that allows having an at least constant stock of trees, whereat the usage of this management practice dates back to the sixteenth century (Weber-Blaschke et al. 2005). However, it was not until the groundbreaking book "Silent Spring" by Rachel Carson in 1962 that a debate about sustainability gained momentum in the political arena (Ishwaran 2012; Shrivastava and Berger 2010). It was not only a book about the adverse effects of industrial agriculture, but also a book giving rise to the understanding of the interconnectedness and complexity of the socioeconomic system (Hardin 1970).

Whittaker and Likens (1975) outlined human's predisposition to reacting to complex problems with a quick fix, tackling symptoms instead of dealing with the cause of the problem, in an early scientific contribution discussing human appropriation of net primary production. Weak sustainability is the quick fix that has been pursued in the political arena and has been supported by many economists.

The concept of sustainability is teleological, striving toward a certain normative goal (Costanza and Patten 1995). The sustainability challenge consists of a transition from an unsustainable state to a sustainable one. It was outlined above that it is acknowledged that the current economic system is understood to be unsustainable, which is why the shift toward the Green Economy is proposed. However, such a shift means not a shift toward sustainability, but rather the continuation of the current system. As explained, the Green Economy is in line with weak sustainability and thus calls for decoupling. Anyway, decoupling has been one of the driving forces at the origin of the current unsustainable economic system. As was briefly indicated, this decoupling had major drawbacks, and has been partially creating the sustainability problems we are facing now. This idea of the Green Economy follows, therefore, exactly the same evolutionary pathway as our current economy. Hence, it is not as Pearce argued that we did not try this path; we tried it already and it failed. It would be illogic to employ the same mechanisms as solution that created the problem (Kastenberg et al. 2005).

Understanding the current economic system as being based on weak sustainability, leads to the deduction that weak sustainability does not exist, as the current economic system is identified as being unsustainable. More precisely, it shows that weak sustainability does not lead to any form of a sustainable future. Thus, the interpretation of weak sustainability is a contradiction in itself and thus should be abandoned. Identifying the weak sustainability concept as illegitimate and accepting this fact, allows to end the discussion between weak and strong sustainability and to pursue the latter one. This allows human society to move beyond the development path that was set out in the second half of the twentieth century, to pass the stage of "mass consumption" (Rostow 1969) and to enter the stage of sustainability.

Acknowledgements The authors would like to thank the reviewers for their time and their comments on the draft version. This paper was supported by the Horizon 2020 project SUFISA (Grant Agreement No. 635577). 
Open Access This article is distributed under the terms of the Creative Commons Attribution 4.0 International License (http://creativecommons.org/licenses/by/4.0/), which permits unrestricted use, distribution, and reproduction in any medium, provided you give appropriate credit to the original author(s) and the source, provide a link to the Creative Commons license, and indicate if changes were made.

\section{References}

Alcott, B. (2005). Jevons' paradox. Ecological Economics, 54(1), 9-21. doi:10.1016/j.ecolecon.2005.03. 020 .

Alcott, B. (2008). The sufficiency strategy: Would rich-world frugality lower environmental impact? Ecological Economics, 64(4), 770-786. doi:10.1016/j.ecolecon.2007.04.015.

Altieri, M. A. (1998). Ecological impacts of industrial agriculture and the possibilities for truly sustainable farming. Monthly Review, 50(3), 60-71.

Andrady, A. L., \& Neal, M. A. (2009). Applications and societal benefits of plastics. Philosophical Transactions of the Royal Society B: Biological Sciences, 364(1526), 1977-1984. doi:10.1098/rstb. 2008.0304.

Behrens, A., Giljum, S., Kovanda, J., \& Niza, S. (2007). The material basis of the global economy: Worldwide patterns of natural resource extraction and their implications for sustainable resource use policies. Ecological Economics, 64(2), 444-453. doi:10.1016/j.ecolecon.2007.02.034.

Blowers, A. (2011). Why Fukushima is a moral issue? The need for an ethic for the future in the debate about the future of nuclear energy. Journal of Integrative Environmental Sciences, 8(2), 73-80. doi:10. 1080/1943815X.2011.585760.

Brand, U. (2012). Green economy \& \#8211; the next oxymoron? No lessons learned from failures of implementing sustainable development. GAIA-Ecological Perspectives for Science and Society, 21(1), 28-32.

Burton, I. (1968). The quality of the environment: A review. Geographical Review, 58(3), 472-481. doi:10. 2307/212567.

Clark, W. C., \& Dickson, N. M. (2003). Sustainability science: The emerging research program. Proceedings of the National Academy of Sciences, 100(14), 8059-8061. doi:10.1073/pnas.1231333100.

Cole, M., Lindeque, P., Halsband, C., \& Galloway, T. S. (2011). Microplastics as contaminants in the marine environment: A review. Marine Pollution Bulletin, 62(12), 2588-2597. doi:10.1016/j. marpolbul.2011.09.025.

Costanza, R., \& Patten, B. C. (1995). Defining and predicting sustainability. Ecological Economics, 15(3), 193-196. doi:10.1016/0921-8009(95)00048-8.

Csereklyei, Z., \& Stern, D. I. (2015). Global energy use: Decoupling or convergence? Energy Economics, 51, 633-641. doi:10.1016/j.eneco.2015.08.029.

Daly, H. E. (1996). Beyond growth: The economics of sustainable development. Boston: Beacon Press.

Davies, G. R. (2013). Appraising weak and strong sustainability: Searching for a middle ground. Consilience: The Journal for Sustainable Development, 10(1), 111-124.

Dittmar, M. (2012). Nuclear energy: Status and future limitations. Energy, 37(1), 35-40. doi:10.1016/j. energy.2011.05.040.

Duffey, R. B. (2005). Sustainable futures using nuclear energy. Progress in Nuclear Energy, 47(1-4), 535-543. doi:10.1016/j.pnucene.2005.05.054.

Ekins, P., Simon, S., Deutsch, L., Folke, C., \& De Groot, R. (2003). A framework for the practical application of the concepts of critical natural capital and strong sustainability. Ecological Economics, 44(2-3), 165-185. doi:10.1016/S0921-8009(02)00272-0.

FAO. (2011). The state of the world's $H$ land and water resources for food and agriculture the state of the world's land and water resources for food and agriculture: Managing systems at risk. Retrieved from London, Rome: http://www.fao.org/docrep/017/i1688e/i1688e.pdf.

FAO. (2016). http://faostat3.fao.org/browse/Q/*/E. Retrieved 26 May 2016.

FoEI. (2009). Overconsumption? Our use of the world's natural resources. Retrieved from http://www.foei. org/wp-content/uploads/2014/08/Overconsumption_Sep09.pdf.

Foley, J. A., Ramankutty, N., Brauman, K. A., Cassidy, E. S., Gerber, J. S., Johnston, M., et al. (2011). Solutions for a cultivated planet. Nature, 478(7369), 337-342. http://www.nature.com/nature/journal/ v478/n7369/abs/nature10452.html\#supplementary-information.

Gómez-Baggethun, E., de Groot, R., Lomas, P. L., \& Montes, C. (2010). The history of ecosystem services in economic theory and practice: From early notions to markets and payment schemes. Ecological Economics, 69(6), 1209-1218. doi:10.1016/j.ecolecon.2009.11.007. 
Haberl, H., Fischer-Kowalski, M., Krausmann, F., Weisz, H., \& Winiwarter, V. (2004). Progress towards sustainability? What the conceptual framework of material and energy flow accounting (MEFA) can offer. Land Use Policy, 21(3), 199-213. doi:10.1016/j.landusepol.2003.10.013.

Hardin, G. (1970). To trouble a star: The cost of intervention in nature. Bulletin of the Atomic Scientists, 26(1), 17-20. doi:10.1080/00963402.1970.11457756.

Hediger, W. (1999). Reconciling "weak" and "strong" sustainability. International Journal of Social Economics, 26(7/8/9), 1120-1144. doi:10.1108/03068299910245859.

Huesemann, M. H., \& Huesemann, J. A. (2008). Will progress in science and technology avert or accelerate global collapse? A critical analysis and policy recommendations. Environment, Development and Sustainability, 10(6), 787-825. doi:10.1007/s10668-007-9085-4.

Ishwaran, N. (2012). Science in intergovernmental environmental relations: 40 Years of UNESCO's man and the biosphere (MAB) programme and its future. Environmental Development, 1(1), 91-101. doi:10.1016/j.envdev.2011.11.001.

Jabareen, Y. (2008). A new conceptual framework for sustainable development. Environment, Development and Sustainability, 10(2), 179-192. doi:10.1007/s10668-006-9058-z.

Juma, C. (2002). The global sustainability challenge: From agreement to action. International Journal of Global Environmental Issues, 2(1-2), 1-14. doi:10.1504/IJGENVI.2002.000985.

Kastenberg, W. E., Hauser-Kastenberg, G., \& Norris, D. (2005). A new way of thinking about sustainability, risk and environmental decision-making. In P. A. Wilderer, E. D. Schroeder, \& H. Kopp (Eds.), Global sustainability: The impact of local cultures, a new perspective for science and engineering, economics and politics (pp. 87-93). Weinheim: Wiley-vch Veralg GmbH \& Co. KGaA.

Kessler, G. (2002). Requirements for nuclear energy in the 21 st century nuclear energy as a sustainable energy source. Progress in Nuclear Energy, 40(3-4), 309-325. doi:10.1016/S0149-1970(02)00024-0.

Krausmann, F., Gingrich, S., Eisenmenger, N., Erb, K.-H., Haberl, H., \& Fischer-Kowalski, M. (2009). Growth in global materials use, GDP and population during the 20th century. Ecological Economics, 68(10), 2696-2705. doi:10.1016/j.ecolecon.2009.05.007.

Krysiak, F. C. (2006). Entropy, limits to growth, and the prospects for weak sustainability. Ecological Economics, 58(1), 182-191. doi:10.1016/j.ecolecon.2005.07.017.

Meadows, D. (2010). Die Grenzen des Denkens: Wie wir sie mit System erkennen koennen und ueberwinden koennen (K. Bossel \& H. Bossel, Trans.). Muenchen: oekom.

Nel, W., \& Ward, J. (2015). Towards a rational sustainability framework. Sustainability Science, 10(3), 515-520. doi:10.1007/s11625-014-0279-z.

Olivier, J. G. J., Van Aardenne, J. A., Dentener, F. J., Pagliari, V., Ganzeveld, L. N., \& Peters, J. A. H. W. (2005). Recent trends in global greenhouse gas emissions: Regional trends 1970-2000 and spatial distribution of key sources in 2000. Environmental Sciences, 2(2-3), 81-99. doi:10.1080/ 15693430500400345.

Pearce, D. (1992). Green economics. Environmental Values, 1(1), 3-13. doi:10.3197/096327192776680179.

Pearce, D., Markandya, A., \& Barbier, E. B. (1989). Blueprint for a green economy. London: Earthscan.

Pimentel, D., \& Patzek, T. W. (2005). Ethanol production using corn, switchgrass, and wood: Biodiesel production using soybean and sunflower. Natural Resources Research, 14(1), 65-76. doi:10.1007/ s11053-005-4679-8.

Pinstrup-Andersen, P., \& Hazell, P. B. R. (1985). The impact of the green revolution and prospects for the future. Food Reviews International, 1(1), 1-25. doi:10.1080/87559128509540765.

Quental, N., Lourenço, J. M., \& da Silva, F. N. (2011). Sustainability: Characteristics and scientific roots. Environment, Development and Sustainability, 13(2), 257-276. doi:10.1007/s10668-010-9260-x.

Redclift, M. (2005). Sustainable development (1987-2005): An oxymoron comes of age. Sustainable Development, 13(4), 212-227. doi:10.1002/sd.281.

Rockstrom, J., Steffen, W., Noone, K., Persson, A., Chapin, F. S., Lambin, E. F., et al. (2009). A safe operating space for humanity. Nature, 461(7263), 472-475.

Rostow, W. W. (1969). The stages of economic growth: A non-communist manifesto. Cambridge.

Scott, D. (2011). The technological fix criticisms and the agricultural biotechnology debate. Journal of Agricultural and Environmental Ethics, 24(3), 207-226. doi:10.1007/s10806-010-9253-7.

Shrivastava, P., \& Berger, S. (2010). Sustainability principles: A review and directions. Organization Management Journal, 7(4), 246-261. doi:10.1057/omj.2010.35.

Smith, P. (2013). Delivering food security without increasing pressure on land. Global Food Security, 2(1), 18-23. doi:10.1016/j.gfs.2012.11.008.

Smith, P., Clark, H., Dong, H., Elsiddig, E. A., Haberl, H., Harper, R., House, J., Jafari, M., Masera, O., Mbow, C. (2014). Agriculture, forestry and other land use (AFOLU). Retrieved from Cambridge, United Kingdom and New York, NY. 
Song, J.-D. (2009). Bertrand equilibrium with differentiated products considering fixed costs: Korean price regulation in the mobile telephone industry. Telecommunications Policy, 33(10-11), 676-685. doi:10. 1016/j.telpol.2009.08.003.

Steffen, W., Persson, Å., Deutsch, L., Zalasiewicz, J., Williams, M., Richardson, K., et al. (2011). The anthropocene: From global change to planetary stewardship. Ambio, 40(7), 739-761. doi:10.1007/ s13280-011-0185-X.

Steinberger, J. K., \& Roberts, J. T. (2010). From constraint to sufficiency: The decoupling of energy and carbon from human needs, 1975-2005. Ecological Economics, 70(2), 425-433. doi:10.1016/j. ecolecon.2010.09.014.

Tilman, D., Fargione, J., Wolff, B., D’Antonio, C., Dobson, A., Howarth, R., et al. (2001). Forecasting agriculturally driven global environmental change. Science, 292(5515), 281-284. doi:10.1126/science. 1057544.

Trucost. (2013). Natural capital at risk: The top 100 externalities of business. Retrieved from http://www. trucost.com/published-research/99/natural-capital-at-risk-the-top-100-externalities-of-business. http:// www.trucost.com/_uploads/publishedResearch/TEEB\%20Final\%20Report\%20-\%20web\%20SPv2.pdf

UNDESA. (2012). A guidebook to the green economy issue 1: Green economy, green growth, and lowcarbon development-History, definitions and a guide to recent publications. Retrieved from https:// sustainabledevelopment.un.org/index.php? page $=$ view \& type $=400 \& n r=634$.

UNEP. (2008). UNEP yearbook 2008: An overview of our changing environment. Retrieved from http:// www.unep.org/yearbook/2008/.

UNEP. (2009a). Global green new deal policy brief. Retrieved from http://www.unep.org/pdf/A_Global_ Green_New_Deal_Policy_Brief.pdf.

UNEP. (2009b). UNEP yearbook 2009: New science and developments in our changing environment.

UNEP. (2010). UNEP yearbook 2010: New science and developments in our changing environment. Retrieved from http://www.unep.org/yearbook/2010/.

UNEP. (2011a). Towards a green economy report: Pathways to sustainable development and poverty eradication. Retrieved from http://web.unep.org/greeneconomy/sites/unep.org.greeneconomy/files/ field/image/green_economyreport_final_dec2011.pdf.

UNEP. (2011b). UNEP yearbook 2011: New science and developments in our changing environment. Retrieved from http://www.unep.org/yearbook/2011/.

van den Bergh, J. C. (2001). Ecological economics: Themes, approaches, and differences with environmental economics. Regional Environmental Change, 2(1), 13-23. doi:10.1007/s101130000020.

Van Hoogstraten, H. D. (2001). Deep economy: Caring for ecology, humanity and religion. Cambridge: James Clarke and Co.

Van Mierlo, J., \& Maggetto, G. (2007). Fuel cell or battery: Electric cars are the future. Fuel Cells, 7(2), 165-173. doi:10.1002/fuce.200600052.

Vitousek, P. M., Mooney, H. A., Lubchenco, J., \& Melillo, J. M. (1997). Human domination of earth's ecosystems. Science, 277(5325), 494-499. doi:10.1126/science.277.5325.494.

WCED. (1987). Report of the World Commission on Environment and Development: Our common future. Retrieved from http://www.un-documents.net/our-common-future.pdf.

Weber-Blaschke, G., Mosandl, R., \& Faulstich, M. (2005). Histroty and mandate of sustainability: From local forestry to global policy. In P. A. Wilderer, E. D. Schroeder, \& H. Kopp (Eds.), Global sustainability: The impact of local cultures, a new perspective for science and engineering, economics and politics (pp. 5-19). Weinheim: Wiley-vch Veralg GmbH \& Co. KGaA.

Whittaker, R. H., \& Likens, G. E. (1975). The biosphere and man. In H. Lieth \& R. H. Whittaker (Eds.), Primary productivity of the biosphere (pp. 305-328). Berlin: Springer.

Wilson, L. (2013). Shades of green: Electric Cars' carbon emissions around the globe. Retrieved from http://shrinkthatfootprint.com/wp-content/uploads/2013/02/Shades-of-Green-Full-Report.pdf.

Wright, S. L., Thompson, R. C., \& Galloway, T. S. (2013). The physical impacts of microplastics on marine organisms: A review. Environmental Pollution, 178, 483-492. doi:10.1016/j.envpol.2013.02.031. 